\title{
DIE FILOSOFIE VAN SMUTS EN BOODIN.
}

\section{A. INLEIDING :}

Die werk van generaal Smuts, baie goed bekend onder die titel „IIolism and Evolution", en sy artikel oor ",ome recent scientific advances in their bearing on philosophy" in "Our Changing worldview", asook die werke van J. E. Boodin, professor in die wysbegeerte aan die Universiteit van California, Los Angeles, "Cosmic Evolution 1925, "Threc interpretations of the Univense" 1934 en „God" 1934, toon die besondere en kenmerkende gedagtegang van dic filosofie van die laaste tiental jare aan. Die kenmerkende is dit dat dit 'n filosofie is van sintese of, soos Whitehead dit ook noem, die filosofie van die ,organisme". Hlierdie sintetiese karakter van dic filosofic is die wysbegeerte eie teenoor dic meganiese en meganistiese verklaringswyse van die dinge met die grondmetode van analise, volgens die denkrigting van die negentionde eeu.

Die filosofie van die twintigste eeu, is die filosofie van sintese en versoening. Die bande tussen die verskillende wetenskappe soos fisika, astronomie, biologie, psigologie ens., word nouer aangchaal. Verder nog, volgens hierdie gedagtegang in die filosofie, staan ook geloof en wetenskap unie langer antagonisties teenoor mekaar nie, maar vorm al die wetenskappe asook die wetenskap van die teologie integrerende dele in die groot wetenskapsgebou gesien as 'in ,,whole." Onder die invloed van Spencer met sy adaptasieteorie, Einstein met sy relatiwiteitsteorie, Bergson met sy begrip van "l'élan vital" in die proses van ewolusie, Alexander met sy hipotese dat ruimte en tyd nie langer as van mekaar onafhanklike entiteite beskou moet word nie, maar as liuimte-Tyd in afhanklikheid van mekaar, moes die uneganiese en meganistiese plek maak vir die organiese.

Meer nog, dis 'n filosofie van sintese omdat ook en veral op die gebied vall dic wysbegeerte self die kenmerkende en fundamentele gedagte opkom, dit is $\mathrm{nl}$. dat sowel kenteoreties as kosmologies die probleme respektiewelik opgelos word deur 'n sintetiese beginsel te aanvaar wat alle teëstellinge ondervang en versoen op 'n hoüre basis van eenheid of ,whole". Die ou verskil in dic kenteorie oor die relasic van subjek en objek word opgehef in die sintetiese eenheid van dic ervaring; en sulke probleme soos kontinuiteit en diskontinuïteil, die verhouding van siel en liggaam, meganisme en teleologie, val weg, omdat die opvatting van die kosmos as ,,whole" en alle dinge as organies met mekaar in betrekking staande, ruimte gee aan al die op die oog teenstrydige beginsels on sake. „The salvation 
for which we long is today no longer found in the acquisition and preservation of a strictly formalistic attitude of mind and mode of knowledge." (Liebert.)

Boodin stel die epog in die wysbegeerte analong mel die krisis in die Griekse filosofic van die vyfde eeu v. Chr. Toe het Aristophanes, omdat Democritus 'n sterk meganistiese wêreldbeskouing voorgestaan het, uitgeroep: Zeus is onttroon en die toeval of geluk is God - en in die negentiende eeu, meen Boodin, het dieselfde gebeur: Zeus is onttroon, daar is geen saamvattende, alles insluitende wêreldbeeld nie, maar deur die meganistiese wêreldbeskouing het ons 'n gaotiese wêreldbeeld. Daarom moet die wysbegeertc (volgens Boodin) op die basis van 'n geordende en afgeronde wêreldbeeld gestel word. Soos Plato met sy kragtige denkvermoë die beskoning oor dic wêreld en oor die lewe omgeskep het van gaos tot kosmos, so wil ook die denkers van die twintigste eeu weer orde bring in 'n wêreld- en lewensbeskouing wat deur die meganistiese opvatting oor die dinge, baic verongelyk is.

Dieselfde grondgedagte vind ons in die filosofie van Smuts. Volgens die prinsipe van meganisme is die essensiële karakter selfs van die hoogste ontwikkelingsprodıkte van enige natuurproses uitgedruk deur hulle aan te toon slegs as baie gekompliseerde gevalle van dieselfde soort aksie en dieselfde intrinsieke $k$ waliteite as wat vertoon is in die laere en meer eenvoudige gebeure. Van thierdie standpunt beskou, is lewe niks anders as 'n gekompliseerde toestand van materie, denke en bewussyn slegs loogsontwikkelde vorme van lewe . . . . volgens hierdie beginsel is enige soort ,whole" of cenheid niks anders as die som van sy dele nie. Dis die analitiese en $k$ wantitatiewe metode om dinge te reduseer tot hulle eenvoudigste clemente. Ilierteenoor die filosolie van sintese, om dinge te sien as dele van 'n ",whole", nog meer om ,wholeness" te sien in elke afsonderlike ding.

Met die oog op hierdie denkrigting voorsê Prof. Forsyth ,,that further developments of philosophy and science will tend to a fuller reconciliation and no mere abstract opposition of the two great historic cosmologies." (Plato en Newton). Smuts sê: Ilolisme is 'n fundamentele sinteties ordenende, organiserende, regulerende aktiwiteit. ,All evolution then, becomes the manifestations of a specific universal activity."

\section{B. DIE SINTESE-FILOSOFIE BY BOODIN EN SMUTS:}

Hierdie sintetiese karakter van die filosofie van Boodin en Smuts kom duidelik uit in die verskillende ooreenstemmende filosofiese begrippe wat hulle besig. 
(a) Kreatiewe Ewolusie:

Materic, lewe en gees (die piramide van Morgan) is nie langer meer diskontinue en disparate verskynsels nie, maar hulle verskyn as ontwikkelingsfases in die groot proses van ontwikkeling. 'n Klimmende skaal van tipes met 'n gedurig verdiepende karakter van indiwidualiteil ontploni sig. Die groot vraag is: Is daar tuie 'n fundamentele beginsel waurvan nuaterie, lewe en gees ontwikkelingsfascs is nie? Is daar nie 'n sintetiese samehang nie? Die on megenisliese opvatting van ontwikkeling het geleer dat alle realiteit gegee is in vorm en substansie, in die begin inplisiet, en dan volg daar alleenlik 'n verdere ontplooiing. In hierdie opvatting is alle inisiatief uitgesluit. Boodin noem hierdie opvatting ook ,Preformation". Beide Smuts en Boodin sê dat ons meer nodig het. Nie net ewolusie nie, maar kreatiewe ewolusie; dus nie blont .,emergence" nie, maar ook, en hicr lè weer die sintetiese gedagte in opgesluit, skepping van nuwc vorme en ontwikkelingsfases. Stel 'n minimum aan die begin van die proses en maak die proses van ewolusie kreatief. Hierdie skeppingsbeginsel in die proses bring sintese en samchang en stel 'n organiese verband tussen die dinge wat in die ontwikkeling ,emerge'. Die reële werklikheid is dan nie net 'n blote beginsel of 'n struktuur nie, of ook anders genoem ,,a disembodied soul or soulless mechanism" nie. Ilier kom volgens Smuts die algemene in die besondere tot sy reg. Die universele verwesenlik homself in en deur die individuele liggame en leite. Hierdie ewolusie dan, met die organies-sinteties skeppende beginsel, druk die werklikheid uit nie as 'n blote ontvouing van wat reeds implisiet anwesig is nie; dis die progressiewe formasie van wat werklik nuut is, alhoewel gebaseer op die oue en nie 'n blote herrangskikking van samestellende dele sonder enige nuwe kenmerk in die ,whole" nie. Boodin sê: ,Our conception of evolution is that of the emergence of a scale of grades of organization under cosmic control". Volgens hierdie opvatting van die ewolusieproses beteken lewe 'n nuwe krag van regulering en aanpassing, gees 'n nuwe krag van oriëntering, denke 'n nuwe krag van organisasie, wat uitgroei uit kondisies wat hulle weer op hulle beurt, wanneer thulle in die ontwikkelingsproses verskyn, bou en modifieer langs weë en op 'n wyse wat inie tevore moontlik was nie. So is b.v. , ,mind no merc continuation and development of the organic process, but largely a fresh experiment in the Universe".

(b) „Wholeness" (Holisme).

Beide Smuts en Boodin lê besondere nadruk op dic begrip van "whole" as die sintetiese, saamvattende beginsel van die hele 
kosmos. Hulle sien altwee in die ,whole" die sintese van dic geheel en die deel, van die universele en die besondere, van die teleologiese en meganiese, die kontinue en diskontinue. Die verskil by hierdie twee denkers is alleenlik dit: Smuts aksentucer die deel in die geheel, Boodin die geheel as insluitende die dele, en verder ook wat die onderlinge wisselwerking betref, stel Smuts die wisselwerking afhanklik van ,,wholeness", - terwyl Boodin ,,wholeness" afhanklik stel van "Cosmic control" of ,,interaction". Smuts sê dat „Holism" die naam is om aan te dui die fundamentele faktor werksaam in die skepping van ,,whole" in dic uniwersum. So is elke organisme 'n geheel, b.v. plant, dier, met 'n eie aard met 'n sekere mate van selfbepaling. "Wholes are basic to the character of the Universe, in Holism is the ultimate principle of the Universe". IIolism los al die heterogene konsepsies van materie, lewe en gees op, en dan kristalliseer daaruit homogene vorme. - Die vlak wat kontinuïteit bied vir die ontwikkeling, is die ,whole-field" - so 'n organiese ,field"' is 'n kontinue wat alle verlede bevat en wat nog werksaam is orn die hede en toekoms te bcïnvloed. Boodin erken die ,emergence" van nuuthede, maar in teëstelling tot die materialisme loop hierdic gebeure af en bewceg hulle binne ,wholes" en bestaan hulle binne 'n universele geheel. Die struktuur in die besondere gevalle verskyn onder die leiding van die ,,whole'. Binne die geheel is die materiële orde decl van die lewende orde, en die lewende orde deel van die geestelike orde. By Smuts en Boodin is daar die opvatting dat daar 'n kwaliteit van die geheel teenwoordig is in al die dele, en dis hierdie kwaliteit van die geheel wat 'n klip meer maak as net 'n klip as samestelling uit sekerc bestanddele, en so ook 'in mens meer maak as 'n mens, bestaande uit bepaalde liggaamsdele en sielfunksies.

(c) Dic Dinamiese:

Boodin beweer dat daar 'n goddelike stroom van energie is wat gaan deur ruimte en tyd en 'n hoeveeliheid energie oordra op stof, wat materie, lewe en gees deurtrek. Die onderlinge verwekking van dele binne die kosmiese geheel, fisiologies en sosiaal is deur middel van energic-vorme wat deel vir deel beïnvloed. Dis nie gewone energie, maar die besondere energie wat vorm aanbring. Smuts neem ook die begrip van die dinamiese as grondleggend en duş essensieel vir hierdie sintetics gekarakteriseerde filosofic. ,Wholeness is the most characteristic expression of the nature of the Universe in its forward movement in time," en verder ,Holism is the inner driving force behind that process, it is the motive force behind evolution." "We live in a world of flux, transition, trans- 
formation" (Boodin). llierdie dinamiese beginsel is die bepaler van die uniwersum sodanig dat deur hicrdie beginsel as ,,inner force" (Smuts) of as ,energy-pattern" (Boodin) die kosmos as 'n geheel ontwikkel. Ilierteenoor staan die wysbegeerte van Bradley en Bosanquet. Ilulle ,,absolute" is 'n statiese totaliteit, logiese stabiliteit en saamvattende harmonic wat as insluitende eenheid in sy statiese vorm opneem al die verskeidenhede van kleur, beweging en ",finite selves". Smuts druk dit so uit: Die meganistiese en statiese alles apart houdende beginsel is oorskadu deur die sintetiesholistiese dinamiese skeppingsbeginsel.

\section{(d) Adaplasic en omgewing:}

Veral in dic filosofic van Boodin speel hierdie begrippe 'n besonder groot rol. Ihule is essensieel on fundamentecl nodig in die verklaring van die kosmos in sy sinteliese ecnheid en ,,wholeness". Sonuts sề dat on die volle verklaring van enigiets te hê, ons die iets moet sien in sy , referonce" tot die tendens na sintese of ,wholeness" met sy begeleiding van nuwe kwaliteite en ontwikkelingsfases van bestaan. Sal die kosmiese ewolusie werklikheidsgetrou wees, dien moct daar wees 'n verskeidenheid van energievlakke on hulle moet in wisselwerking met en in betrekking tot mekaar staan, sodat daar ook sal wees onderlinge inwerking. Verder, oursaak en gevolg dek rie altyd tenvolle mekaar nic, daar is nog 'n ander beginsel nodig en dit is omgewing. ,The environment must ultimately furnish the impetus to advance and suggest the pattern" (Boodin). Daar is dus preference" deur die hele proses heen. ,We must recognize degrees of plasticity of selective adaptation all the way from the electron to man." Adaplasie en omgewing - hierdic I wee begrippe bepaal verder die filosofie van smuts en Boodin as filosofie van sintese. Materie, lewe en so ook gees staan nie los van die omgewing nic, nee rlaar is onderling relasic en kontrole. Niks in die kosmos bestaan sonder verband nie - dinge is nic kopieë van tevore bestalande verbind nie, nee, dinge is geskep in die verband. Beide die menslike organisme, fisies en psigies, en dic omgewing is sinteties verbind in dic ervaring.

(e) Hoewel beide Boodin en Smuts verteenwoordigers is van die filosofie van sintese, verskil die twee groot denkers tog in die finale afronding van hulle sisteme. Boodin is baic sterk beïnvloed deur die Grickse filosofie en veral deur die kosmologie van Plato as synde teleologies tecnoor dic meganistiese opvattinge van Demokritus. Boodin mak die onderskeiding van ideële en reële. Lin om die twee te versoen nl. idee en verskyning is nodig die ewolusieproses - en nimate dic reële hom anpas by dic ideëte, na die mate 
slyg die werklikheid van die verskyninge en na die mate is hulle kompleter en volmaakter. Dic vorm wat leiding gee staan bo-aan. Nie só dat die vorm inhoudloos moel wees nie. Die vormgewende persoon of saak is die ,cosmic genius". Deur die proses van realisasie en adaptasie aan die cen kant en deur die leiding van die .,cosmic control" aan die ander kant ontplooi die kosmos tot 'n staat van volmaaktheid. Presies die teleolngiese kosmologic van Plato met sy , cosmic creative genius" (Demiurg) met die ,,noes" as koördinerende boginsel. Boodin rond sy sisteem af met die begrip van God of wat hy noem: „cosmic genius" - ,which is the mainspring of the upward cosmic nicus from lower to higher levels". "This cosmic: control does not evolve, but everything evolves within it." Dus is dit 'n absolute kontinuum. God is dic gecstelikie ,field" waarin alles lecf en beweeg; die vlak wat an die kosmiesc proses leiding gee. Die sintese van die filosofie van Boodin lề dan cintlik daarin dat al die verskynsels in die kosmos, al dic dinge in die wêreld, dele is, wat hoewel hulle selfstandig beslan tog hulle volle realiteit onlvang in hulle verhouding tot die geheel en hierdie geheel neem by Boodin die vorm aan van 'n kosmiese kontroleur of genie.

Smuts sien in die geheel die deel raak en in dic deel die geheel. Die algemene is vir hom geopenbaar in die besondere. Boodin verdedig die filosofie van Plato, Smuts sc filosofie vertoon o.i. die gedagtes van die filosofic van Aristoteles. By Smuls is universaliteit en individualiteit komplimentêr. Ilolisme verenig die veelheid in die cenheid, in die individu. 'n Geïndividualiseerde ,whole" of ,soul" is die hoogsontwikkelende vorm en dit ken geen bande nie. Om thierdic afronding te bereik het Smuts gebruik gemaak van twee beginsels nl. indeterminisme en holisme. Beide is primêr. Iliervolgens is ewolusie dan 'n klimmende serie van ,,wholes", waarin die mens die hoogste, die mees gekompliseerde maar ook die mees geïndividualiseerde is. Hierdie proses van ewolusic mond uiteindelik uit in die persoonlikheid.

Wat die begrip God is vir Boodin, dit is die begrip van die persoonlikheid vir Sınuts. Persoonlikheid is die hoogste beliggaming van holisme beide in sy individuele en universele tendense, dis die finale sintese van alle werkende faktore. Dis 'n kreatiewe sintese, waarin die vroeëre materiaal organies fisies ingesluit is met 'n nuwe ,,emergence" van holisme. Die probleem van die persoonlikheid is die probleem, waarin al die ander probleme kulmiucer. Smuts sì: .,Personality is the most real of all the reals, the latest and fullest expression of the supreme reality which gives reality to all other reals." Verder, ,it is a new whole of the prior wholes". Persoonlikheid is materie, lewe en gees saamgevoeg en verbind, en tog is dit iets nuuts en meer as hulle almal saam. 
Boodin beklemtoon die vorm (God finaliter) en Smuts beklemtoon die individu, die persoon wat in die ewolusieproses ,energe" as die hoogste.

(f) Die sintetiese karakter van die kenteorie van Smuts en Boodin: Kenteoreties speel ervaring die groot rol in hierdic filosofie van sintese. Dis duidelik volgens die opvattinge van Boodin en Snuts dat en God as die hoogste en die persoonlikheid as die mees gekompliseerde maar nok mees geïndividualiseerde in dic kosmos, in die dinge en in die ontwikkelingslases lewe en rigting angee deur hulle uitlewing of ervaring. Leighton druk dil só uil: hoe meer individualiteit, thoe ryker, des le omvattender en harmonies die aktiwiteite en ervaringe van die , selves". Smuts sê : Deur dic leer van holisme is die menslike subjek geplaas op 'n nuwe oriënteringssentrum. Boodin sê : Ons begin waar ons ons bevind in die menslike gebeure en gaan van daaruit verder totdat die goddelike lig deurbreek in ons siele; en verder, dic menslike crvaring is ryk - ons lewe in 'n wesensrelasie tot die kosmos en maak dcel uit van die dinamiese ,"wholeness" van dinge.

\section{KRITIEK :}

Daar is baie om generaal Smuts en Prof. Boodin mee te krediteer wat betref hulle filosofiese beskouinge. Elkeen het op 'n nuwe wyse sy kosmologie opgestel met die kenmerkende beginsel van sinlese as grondslag. Om die dinge in die kosmos en hulle verband en struktuur, en hulle individualiteit maar ook uniwersaliteit te sien, beteken baic vir die wysbegeerte.

a) Verwarring van begrippe:

(1) Ewolusic: Oor hierdie begrip is daar duisend en een opvattings, afgesien nog van die toepassing van die beginsel van ewolusie op sovecl gebiede van die wetenskap. Jis, soos Schiller dit uitdruk: soos grassaad wat oor die hele wêreld versprei lê en nou ontkiem en orals opkom. Ewolusie is 'n uitstekende begrip om die realiteit van groei vas te stel, maar dis tog bloot vormlik en uiters gebrekkig as 'n verklaringswyse.

(2) Skepping: By die holiste en sintese-filosowe word die begrip gebruik in dic sin van voortbringende iets, wat aanwesig was in dic voorafgaande ontwikkelingsfases, maar iets, wat ook weer nuut is. Is dit nie bloot hipolese nie? Iloe hang hierdie begrip nie in die lug nie? En, hoe swak vergelyk dit nie by, en hoc inhoudloos staan dit mie teenoor die begrip van skepping volgens die Skrif nie? Die gebruik van dic woord by beide denkers is baie kunsmatig. 
(3) Ilolisme: Generaal Smuts het ernstige besware teen ander benaminge in die filosofie, en wat van sy eie $\mathrm{J}$. M. Robertson se dat Smuts met reg te velde trek teen benaminge in die moderne wetenskaplike denke, woorde soos ,,meganies" en ,meganisticse" om biologiese en kosmiese prosesse aan te dui, en tog kulmineer sy eie filosofie in die ,hypostatizing of names" - want wat beteken ,whole", , , a whole", ,the whole"? Dieselfde geld by Boodin. Verder hipostaseer Smuts ,whole" tot ,holism" en spreek daarvan as 'n werklike beginsel, 'n krag, die regerende krag in die univers. McDougrall kritiseer Smuts só: IIolism beginnende as 'n woord wat 'n empiriese generalisasie bevat, word 'n begrip en dan gehipostaseer as 'n ,operative factor, evolves into a telcological agent', wat interaksie hel met meganistiese faktore en die meganistiese faktore domineer hoe verder die ontwikkelingsdrama afspeel totdat dit eindelik die plek inneem van die rede en verhef word byna tot 'n God. Dus bet ons onder hierdie sintetiese begrip van holisme alles ingesluit. ,Holism begins as a descriptive word, becomes a concept, then a concept that is at work in all natural processes and finally a teleological governing agent to which all order and evolution are due."

So nok by Boodin is dit uiters moeilik om te verstain wat beteken b.v. die begrippe ,,cosmic rcligion”, ,wholc”, ,energypattern", ,,energy-complex" ,,energy field" ,energy-levcls". Stout sêt hiervan, ,that purple passages make rather to frequent intrusions into the argument all through, so that where we urgently need cold analysis and definition we may be fobbed off with metaphor and a rather theatrical diction, which fail to be impressive."

Kortom, hierdie begrippe by beide denkers is die mocilike taak opgelê om te vecl gedagtes te dra en bied dus opening tot verwarring. Die siritese-element is so sterk dat die besondere en dic vereiste analitiese en gespesifiseerde verlore gaan.

(b) Terwyl hierdie verhandeling geskrywe is om die filosofie van Smuts on Boodin te sien in die lig van versoeningsfilosofie, sal dit ons te vèr afvoer om b.v. ook te wys op die analogic tussen, maar ook die verskil van, die ontwikkelingsfascs in die sisteem van Boodin en die wetssfere in die stelscl van Vollenhoven en Dooye. weerd.

Nog net hierdie prinsipiële onderskeiding: Die alles-beheersende vraag wat aan elke wysbegeerte gestel word is: Bestaan daar 'n grens tussen God en die geskapene? By die twee denkers het ons versoeningsfilosofie. M.i. sou ons Boodin kan bestempel as 'n panenteis en Smuts as 'n partiel-teis. Beide erken dat daar 'n grons 
is, maar cintlik is die skeiding relatief. Die godsbegrip van Boodin vorm 'n deel van sy wêreldbeskouing. Die opvatting oor die grens lussen God en die geskapene is baie vaag. Ily neig oor na Monisme. en erken slegs 'n graduele verskil tussen God en mens. Smuts met die nadruk wat hy lê op die deel in die geheel, individualiteil teenoor uniwersaliteit neig oor na dualisme, hoewel hy per slot van sake ook maar 'n graduele vershil crken tussen die kosmos en die hoogste persoonlikheid. Hierdeur beskou hy 'n decl van die kosmos tog ook weer as goddelik. Ilierdie versoeningslewe wat aan die een kant alles beskou as bestaande in God (Boodin) en aan die ander kant 'n deel van dic kosmos verhef tot die goddelike of dit nou meer monistics of meer dualisties opgestel is, verskil radikaal van 'n Kalvinistiese of teïstiese wysbegeerte. Op die oog lyk die verskil klein - maar in dic aard van die saak is dit 'n hemelsbreë. Om net te noem die verskil oor die opvatting van die verhouding van God en kosmos, sulke beginsels soos Openbaring, skepping en skeppingordinansies wat 'n teistiese wysbegeerte onvoorwaardelik eie is.

Ventersdorp.

J. M. DE WET. 